\title{
Vocabulary Connect Four Circles (VC4C) Card Game for Malaysian Young Learners' Vocabulary Learning
}

Chai Kar Ni \& Melor Md Yunus

To Link this Article: http://dx.doi.org/10.6007/IJARBSS/v11-i1/8406

DOI:10.6007/IJARBSS/v11-i1/8406

Received: 04 December 2020, Revised: 29 December 2020, Accepted: 12 January 2021

Published Online: 26 January 2021

In-Text Citation: (Ni, \& Yunus, 2021)

To Cite this Article: Ni, C. K., \& Yunus, M. M. (2021). Vocabulary Connect Four Circles (VC4C) Card Game for Malaysian Young Learners' Vocabulary Learning. International Journal of Academic Research in Business and Social Sciences, 11(1), 552-574.

\section{Copyright: (c) 2021 The Author(s)}

Published by Human Resource Management Academic Research Society (www.hrmars.com)

This article is published under the Creative Commons Attribution (CC BY 4.0) license. Anyone may reproduce, distribute, translate and create derivative works of this article (for both commercial and non-commercial purposes), subject to full attribution to the original publication and authors. The full terms of this license may be seen at: http://creativecommons.org/licences/by/4.0/legalcode

\section{Vol. 11, No. 1, 2021, Pg. 552 - 574}

Full Terms \& Conditions of access and use can be found at http://hrmars.com/index.php/pages/detail/publication-ethics 


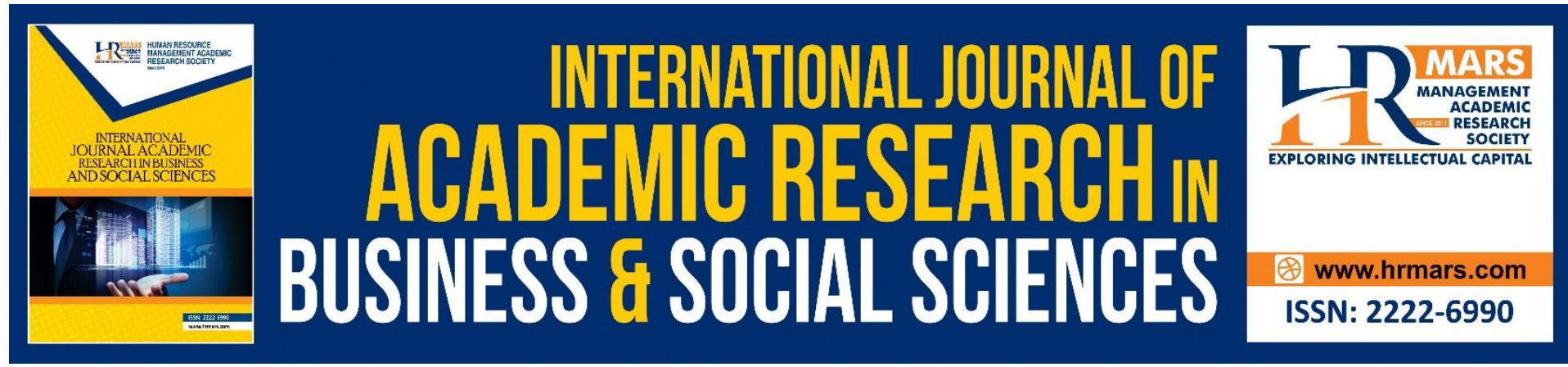

\title{
Vocabulary Connect Four Circles (VC4C) Card Game for Malaysian Young Learners' Vocabulary Learning
}

\author{
Chai Kar Ni ${ }^{1}$ \& Melor Md Yunus ${ }^{2}$ \\ Faculty of Education, Universiti Kebangsaan Malaysia \\ Email: karni21chai@gmail.com ${ }^{1}$, melor@ukm.edu.my²
}

\begin{abstract}
The importance of teaching English as a second language has been given emphasis as stated in the Malaysian Education Blueprint (2013-2025). Past studies had indicated that it was extremely draining and challenging to teach vocabulary to pupils using conventional chalkand-talk methods. In general, pupils were reported to be demotivated and forgetful of the vocabulary items learnt. Hence, this research was carried out to investigate the effects of a teaching intervention on young English language learners' vocabulary acquisition. VC4C (Vocabulary Connect 4 Circles) Card Game is a form of game-based learning that characterises the concepts and principles of two-player connection games, namely Connect Four and TicTac-Toe. Employing an action research design, data were collected through a pre- and posttest, a survey questionnaire and an observation checklist from 24 Year One pupils of an urban school in Bintulu, Sarawak. The data collected were analysed descriptively. The findings of the research showed that majority of the participants had improvements in their vocabulary skills and 4C's (cooperation and collaboration, communication, creative and critical thinking skills) and $1 \mathrm{~V}$ (value). This research had also shone some light on the potential use of VC4C Card Game as ESL learners had better memory retention of the vocabularies learned.
\end{abstract}

Keywords: Vocabulary, Education, Primary Learners, Challenging, Game-Based Learning

\section{Introduction}

Vocabulary is the core element of language aptitude and it reflects how well listeners listen, speak, read and write (Kunnu, Uiphant \& Sukwises, 2016). It is a fundamental aspect to learn the skills of speaking, listening, reading and writing. In order to communicate and learn more, pupils should acquire $3000-4000$ new vocabulary words each year (Alqahtani, 2017; Bakhsh, 2016; Misbah, 2017). This is due to the fact that English as a Lingua Franca (ELF) is the study of the type of language that is used when different second language speakers interact with each other. Moreover, English dominates many cultural areas, such as songs and films. It is also the greatest common language spoken universally (McKay, 2018; Ginsburgh et al., 2016; Nishanthi, 2018). Being the global language of interaction, it is crucial for a person's competencies development. When a person is well proficient in English, it will enable them to excel in the Fourth Industrial Revolution where the market for English as a Second Language is booming (Lie \& Yunus, 2018; Reddy, 2016; Thirusanku \& Yunus, 2012). 
In addition to that, in the Malaysian Education Blueprint (2013-2025) (Ministry of Education, 2018), English is the second language and in order to empower the usage of the language, the Malaysian government has taken different steps such as by imposing Highly Immersive Programme (HIP) and the Dual Language Programme (DLP) to maximise the usage of English in our education system. Thus, second language vocabulary acquisition is fundamental to the mastery of the targeted second language (Yunus \& Ek Hern, 2011; Hariffin \& Said, 2019). With sufficient vocabulary words, pupils can read and understand a reading passage in their textbook.

However, it was undeniable that the pupils were demotivated and unable to remember the spelling and meaning of the words learned. Their academic performance and dominant use of mother-tongue language had indirectly limited the pupils' experience in learning English and thus, affected their vocabulary exposure. In fact, lack of vocabulary skill and active participation from primary pupils are among the challenges faced by teachers in boosting primary pupils' vocabulary (Lim, Yunus \& Amin, 2017; Yunus, Kiing \& Salehi, 2013). Undeniably, it is a challenging task for English language teachers to equip primary pupils with adequate vocabulary even though many teaching strategies have been used to assist them in learning vocabulary (Bakhsh, 2016; Conwell, 2017, Yunus et al., 2020). Within the Malaysian context, the teaching and learning process of vocabulary using the English language textbook in the English language begins as early as Primary 1 and onwards to Primary 6 (Ministry of Education, 2017). The use of English language textbooks to teach and learn vocabulary has demotivated primary pupils to remember the vocabularies learned as they have no interest in it. Moreover, throughout the English language syllabus, the teaching and learning of vocabularies only focused on the use of drilling or using flashcards by decoding, pronouncing and developing connection to the related spoken words (Taylor, Greenberg \& Terry, 2016). Although the drilling strategy or flashcards may work in certain occasions, in the long run, this strategy may not be sufficient to maintain the momentum of the teaching and learning of vocabulary in the aspect of learners' interest, mood and motivation. Therefore, various strategies must be employed to teach and learn vocabularies effectively especially for primary pupils (Nie \& Li, 2017; Rachmawati, 2018).

In line with the teaching and learning of vocabulary, local and international researchers had derived methods and teaching aids within their studies. Both studies of using games to enhance pupils' vocabulary mastery and educational fun and meaningful activities such as Letter Scramble, Chalk Board Acronym, Charades and mini game shows had a great impact in heightening the learning of the vocabularies (Shabaneh \& Farrah, 2019; Bavi, 2018; Perveen, Asif \& Mehmood, 2016). Nonetheless, the teaching aids or learning strategies implemented in those studies focused more on enhancing pupils' vocabulary learning through reading or computerised materials. To date, very little to none of the past researches were conducted using card game-based teaching aids to enhance primary pupils in vocabulary learning. Thus, this paper aims to apply a card game-based teaching and learning aid called the VC4C Card Game to enhance pupils' vocabulary skills in the teaching and learning of vocabulary, aside from inducing a fun and purposeful game to encourage pupils to learn vocabularies meaningfully.

\section{Research Objectives}

- To enhance the vocabulary skills among the young learners.

- To encourage the young learners to learn vocabularies. 


\section{Research Questions}

- How does VC4C Card Game help to enhance the vocabulary skills among the learners?

- How does VC4C Card Game help to encourage the learners to learn vocabularies?

\section{Literature Review}

The following section discusses the literature review related to the research carried out.

Teaching and Learning of Vocabulary

Vocabulary has an important role in linking the four language skills of listening, speaking, reading and writing together (Indriyani \& Sugirin, 2019). However, many primary pupils have low vocabulary acquisition and this hinders them to be well-versed in the target language. Recent studies in second and foreign language acquisition emphasised that second language speakers should acquire a good foundation of vocabulary knowledge to become good users of English in all academic achievement (Viera, 2017). With good vocabulary, pupils will be able to comprehend and express language in better form. In addition, vocabulary is the basic component for language proficiency because it serves as the solid foundation to enable the learners to listen, speak, read and write (Mashhadia \& Jamalifar, 2015). Therefore, emphasis should be given to primary pupils in vocabulary learning as it is very important in the second language acquisition.

\section{Challenges in Vocabulary Learning}

The application of games in this 21st century technological society can assist classroom learning activities because games enable primary pupils to learn vocabulary better than using conventional ways as the pupils can learn vocabularies through fun and meaningful learning (Vygotsky, 1978; Taghiadeh et al., 2017; Shahriarpour \& Kafi, 2014; Takeuchi \& Vaala, 2014; Chai et al., 2020). Studies on the implementation of a computerised game called "Fun Spelling" proved that learners were able to categorise, differentiate and comprehend the different types of vocabularies in a fun way (Saeed \& Ghayour, 2017; Walker and Rinaldi, 2019). In addition, introducing educational games to pupils would also help to create a fun and creative environment in the classroom (Pomerantz \& Bell, 2007). Therefore, employing language learning games that have detailed linguistic contents can be meaningful to encourage pupils who are driven by external component (Segal-Drori et al., 2010; Jan \& Gaydos, 2016; Derakhshan \& Khatir, 2015; Hidayat, 2016; Shabaneh \& Farrah, 2019).

Besides, the usage of games is also effective in vocabulary learning because it usually involves friendly competition among learners and creates a cooperative learning environment for the pupils (Calvo-Ferrer, 2017; Al Neyadi, 2007). While playing the game, pupils interact with each other and as a result, they will have better acquisition of language vocabulary (Pirrie, 2017; Yunus, Salehi \& Amini, 2016). Moreover, pupils who learned through games scored significantly better than the others who used different means of practising vocabulary (Akdogan, 2017). In fact, through vocabulary game, it will help in developing the pupils' interpersonal skills and their vocabulary (Liu \& Liu, 2015; Sousa \& Rocha, 2019).

Last but not least, the core concept of game-based strategies is to assist and teach primary pupils to learn through repetition, failure and achievement of goals. In addition, most game-based learning strategies are compatible with the education curriculum as learners are working towards a goal, selecting appropriate learning actions and experiencing the outcome of the learning actions (White \& McCoy, 2019; Bavi, 2018). Thus, in this research, VC4C Card 
Game was introduced to enhance and encourage the young learners to acquire more vocabularies.

\section{Methodology}

The following section discusses the research methodology employed in this research.

\section{Research Design}

As the focus of this research is to improve the teaching and learning of vocabulary by enhancing vocabulary learning among Primary 1 pupils using VC4C Card Game, an action research design suits this purpose. An action research is a set of systematic and organised design procedures adopted mostly by individuals in an educational setting to collect related data and information in order to enhance the aspects of educational teaching and pupils' learning (Creswell \& Guetterman, 2019; Denscombe, 2014; Dick, 2015).

In this Action Research process, the Lewin (1946) and Laidlaw (1992) Action Research model was adapted. Figure 1 shows the action research model comprises of five important steps which are "identifying problem", "planning action", "implementing action", "observing" and "reflecting and evaluating" (Chuah, 2014; Collatto et al., 2018). The cycle is then repeated where necessary and the original action plan becomes a revised plan. At this point, improvements are included and applied to suit the research focus and objectives for a better intervention process.

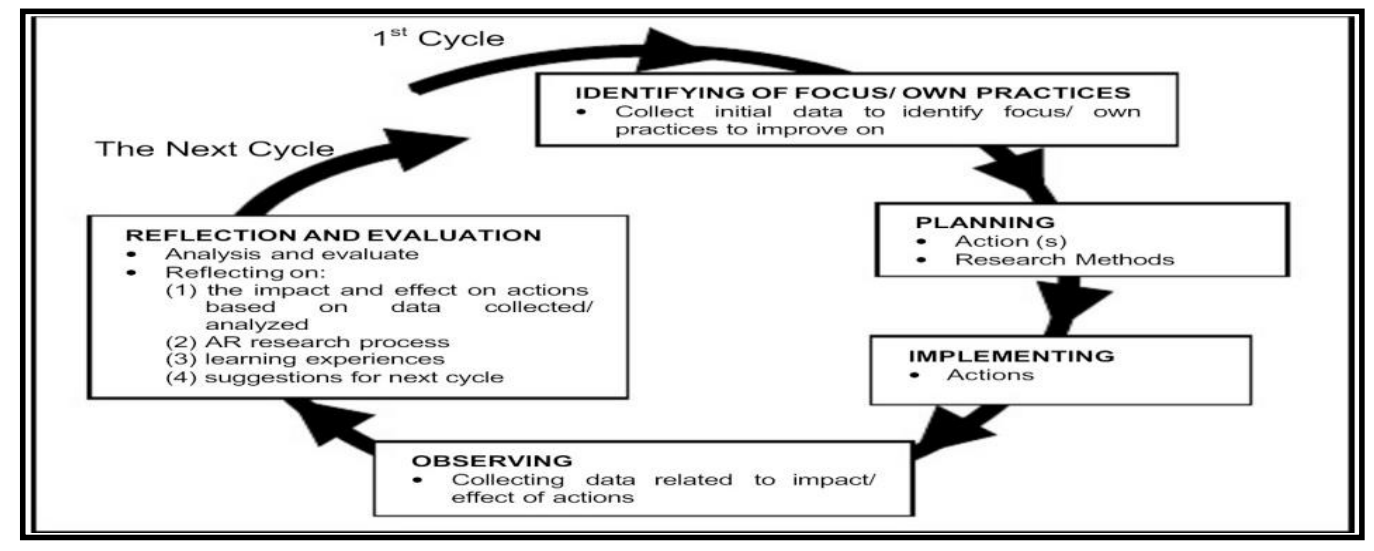

Figure 1: Lewin (1946) and Laidlaw (1992) Action Research model

\section{Research Participants}

The researcher was directly involved in monitoring and instructing the research participants throughout the action research. There were five Primary 1 (age 7) classes in Sekolah Kebangsaan Jaya (pseudonym), an urban primary school in Bintulu, Sarawak. By implementing purposive sampling, Table 1 shows a total of 24 Primary 1 pupils (pseudonym) were selected for this action research. Purposive sampling is one of the sampling techniques where the samples are not given equal chances of being included in the research (Creswell \& Guetterman, 2019; Dick, 2015; Etikan, Musa \& Alkassim, 2016). This small sample size was effective to monitor the implementation process of the VC4C Card Game. The pupils in the class were of "Low Language Proficiency" to "Average Language Proficiency" where they only managed to achieve Performance Level 1 and Performance Level 2. The level of proficiency of the participants was determined by their English language performance recorded in the Pentaksiran Bilik Drajah (PBD) in the beginning of the year 2020. The community in this school 
mainly speaks in the Malay language and their everyday occupations are mainly fishing. Overall, the community in this area is from average to low socioeconomic background.

Table 1: Number of participants

\begin{tabular}{cccc}
\hline The School (District) & Male & Female & Total number of participants \\
\hline $\begin{array}{c}\text { Sekolah Kebangsaan } \\
\text { Jaya (Bintulu) }\end{array}$ & 13 & 11 & 24 \\
\hline
\end{tabular}

\section{Research Instrument}

The selection of instruments for data collection primarily depends on the types, aims and the objectives of a research (Charman, 2017; Chu \& Ke, 2017; Creswell \& Guetterman, 2019). This research had employed a pre-test, a post-test, a survey questionnaire and an observation checklist.

In the early stage of this research implementation, the pre-test (Appendix 1) was administered to collect and analyse the pupils' prior vocabulary skills. The pre-test consisted of two parts with a total of 20 questions. Part one comprised of 20 spelling tests in the form of unscramble the letters while Part Two required the pupils to match the vocabularies that they had spelled with their meanings. The 20 selected vocabularies for the pre-test consisted of the High Frequency Words in the Primary 1 DSKP (Ministry of Education, 2018). For the post-test (Appendix 1), it was administered to gather and examine the Primary 1 pupils' vocabulary skills after the implementation of the VC4C Card Game. The post-test was exactly the same as the pre-test. This is important to see the progress of the pupils in acquiring vocabulary skills after the implementation of VC4C Card Game.

A survey questionnaire (Appendix 2) derived from the Model of Academic Success by York et al. (2015) was administered to measure the Primary 1 pupils' vocabulary learning. According to the model, learning is effective when learners are able to achieve acquisition and success in five main elements. The elements are (1) attainment of learning outcome, (2) satisfaction in learning, (3) persistence in learning, (4) acquired learning skills and (5) performance or academic achievement. The questionnaire consisted of 15 close-ended items, gauging on the vocabulary learning among the Primary 1 pupils. The pupils were required to tick one ranging from "Strongly Agree" to "Strongly Disagree" based on their personal experience on using this VC4C Card Game in learning vocabulary.

An observation checklist (Appendix 3 ) derived from the Model of Academic Success by York et al. (2015) was also administered to gauge the Primary 1 pupils' vocabulary learning. The observation checklist consisted of written remarks to take note of any pupils' behaviours and interaction throughout the implementation of the card game to serve as a triangulation in this research.

\section{Validity of the Research Instruments}

The pre-test and post-test were created based on 20 vocabularies as stated in the High Frequency Words in the Primary 1 DSKP. Since the DSKP was used as the main reference to develop the test items, content validity was achievable as the tests were set to measure the pupils' vocabulary skills based on the intended lists of vocabularies. In order to determine the reliability of the pre and post-tests, the Cronbach's Alpha reliability coefficient was employed based on the given formula(Hambleton \& Li, 2014; Lok et al., 2016). 


$$
\begin{aligned}
& \dot{\alpha}=\frac{k}{k-1}\left(1-\frac{\sum_{i=1}^{L} p_{i}\left(1-p_{1}\right)}{\hat{\sigma}_{x}^{2}}\right) \\
& \text { Notes: } \\
& k \quad=\text { number of items in the test paper } \\
& p_{1}=\text { percentuge of correct responses for cach item, } / \\
& \hat{\sigma}_{x}^{2}=\text { sample variance of total score }
\end{aligned}
$$

Figure 2. Cronbach's Alpha Reliability Coefficient Formula

The pre-test produced a Cronbach's Alpha of 0.854 , while the post-test had a Cronbach's Alpha of 0.843 . These results proved that both tests had achieved high internal consistency and were reliable as both value were more than 0.8 (Nunnally \& Bernstein, 1994).

In order to test the reliability of the questionnaire, after employing the VC4C Card Game and post-test, the pilot participants were given a questionnaire to collect their opinions on the degree to which they agree or disagree to any of the given statements. The statements were rated on a Likert scale of 1 to 5 where " 1 - Strongly Disagree" to " 5 - Strongly Agree". The data from the questionnaire were collected and tabulated into SPSS Version 25 to obtain the Cronbach's Alpha reliability coefficient. As asserted by Taber (2018), Cronbach's Alpha is a measure of scale reliability of which to determine the consistency in relatedness of a set of items within a group. Table 2 shows the reliability statistics of the data collected from the questionnaire.

Table 2: Reliability Statistics of Questionnaire

\begin{tabular}{ccc}
\hline Cronbach's Alpha & $\begin{array}{c}\text { Cronbach's Alpha Based } \\
\text { on Standardized Items }\end{array}$ & N of Items \\
\hline .873 & .875 & 15 \\
\hline
\end{tabular}

\section{Data Collection Method}

Since this study was carried out in the form of an action research, the data collection procedure followed the Lewin (1946) and Laidlaw (1992) cyclical Action Research processes. The pre-test was initiated in the first stage of the action research which was the "identifying problem" stage to identify and prove the issues on pupils' vocabulary learning motivation and vocabulary skills. With the issues identified, they facilitated the second stage which was the "planning for action" stage that featured the development of the VC4C Card Game.

During the "implementation of action" stage, all the 20 targeted vocabularies were introduced by the researchers to the participants using flash cards and word cards. In fact, all the 20 targeted vocabularies were introduced in four periods of lesson, where 5 vocabularies were introduced in each period of the lesson. After the 4th period of lesson, the participants had covered all the 20 vocabularies by using flash cards. In this VC4C Card Game, the participants were divided into two teams with three players for each team. Then, each team was given ten vocabulary cards by the scorekeeper. Every player was required to take turns to read, spell and tell the meaning of the vocabulary in order to cross out a circle in the Connect 4 Circles sheet. The game ended once a team crossed out four circles in a straight line. After the reinforcement activity, the "observing" stage came into action as the researcher administered the post-test, survey questionnaire and observation checklist to 
collect the data with regards to the pupils' motivation and vocabulary learning after the implementation of this VC4C Card Game.

The final step was the "reflecting and evaluating" stage before initiating another cycle of action research. In this stage, collected data were scrutinised and analysed to address the formulated research questions (Creswell \& Guetterman, 2019; Denscombe, 2014). The collected data was analysed accordingly. With the results, reflections and evaluation were done and any point for improvement and amendments were noted for the next cycle.

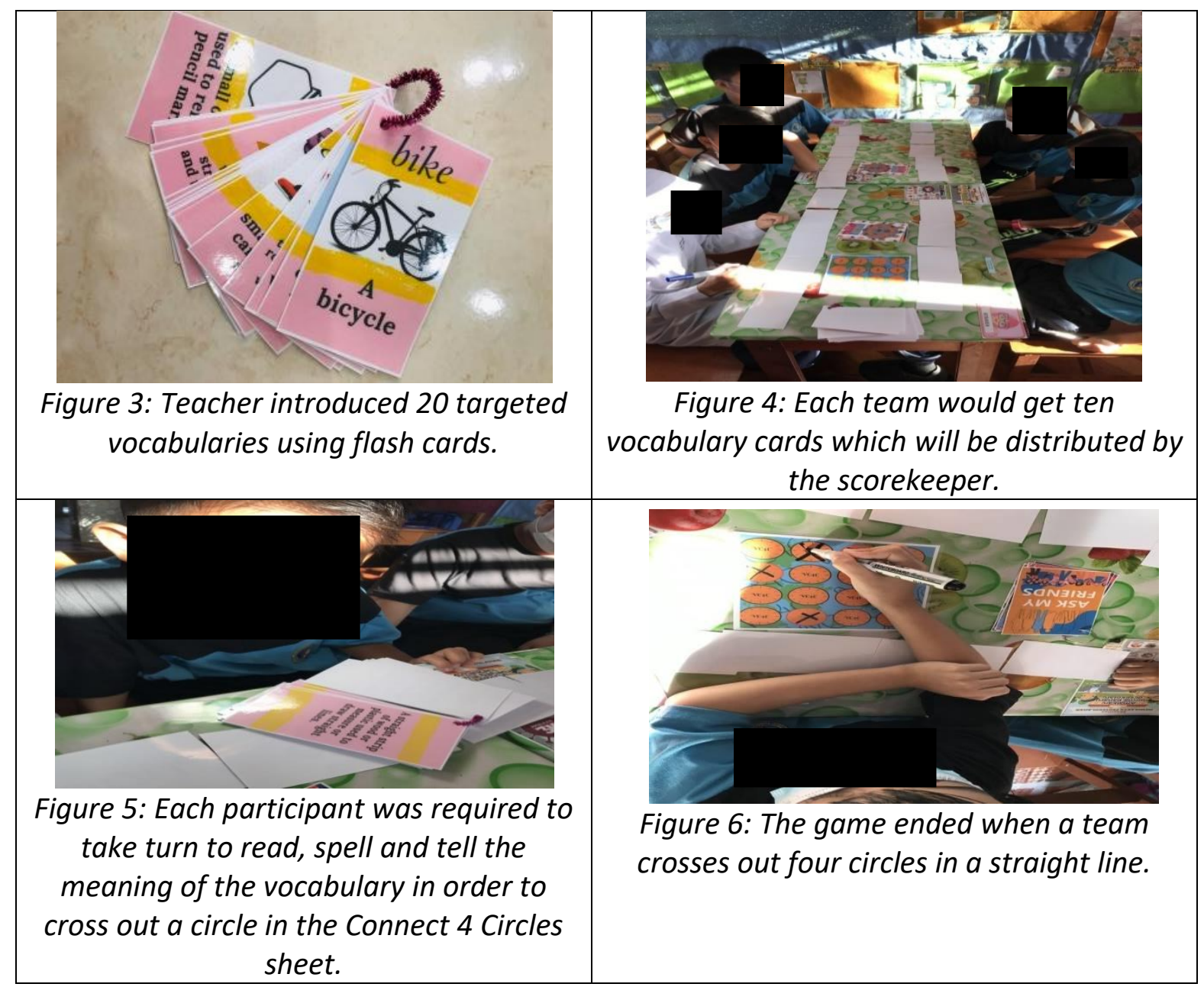

\section{Data Analysis}

In this research, statistical analysis was implemented to examine and scrutinise the data collected for pre-test, post-test and survey questionnaire. After identifying the pupils' scores, they were analysed and inputted into the Statistical Package for The Social Science Version 25 (SPSS Version 25) to get statistical results. Shapiro-Wilk was applied for normality test of the data while effect size was calculated to measure the magnitude of mean differences (Cohen, 1988). Next, the research questions were addressed through the analyses of pairedsample t-test. A paired-sample t-test was used to compare the means of the pre-test and post-test scores obtained in order to determine the effectiveness of vocabulary learning among the participants (Creswell \& Guetterman, 2019).

Apart from the pre-test and post-test, statistical analysis was also carried out on the survey questionnaire. Descriptive statistics in terms of percentage and mean score is suitable to be employed on a series of combined questions that measure a particular trait especially 
for survey questionnaire (Asún, Rdz-Navarro \& Alvarado, 2016). Moreover, throughout the process, the researcher had conducted critical observations by implementing the qualitative measure of observation checklist in order to triangulate the results with the post-test and survey questionnaire. The checklist consisted of written remarks for the researcher to take note of any improvement and motivation in the vocabulary learning. Researcher triangulation was also implemented to identify similarities and differences in the statements, keywords and details of the given remarks.

\section{Findings}

The data had been collected through pre-test, post-test, a survey questionnaire and an observation checklist. To find out if there was a difference between the pre-test and post-test scores, normality test of Shapiro-Wilk was computed to see if the data was normal. Result was presented in Table 3. Next, an analysis of paired-sample t-test was computed. This was to analyse the mean scores of the pre-test and the post-test. The significant level was specified at .05 (alpha, $\alpha=.05$ ). Results were presented in Table 4 and 5.

Table 3: Test of Normality (Shapiro-Wilk)

\begin{tabular}{lccc}
\hline & \multicolumn{3}{c}{ Shapiro-Wilk } \\
\cline { 2 - 4 } & Statistic & df & Sig. \\
\hline Pre-test & .920 & 24 & .058 \\
Post-test & .929 & 24 & .093 \\
\hline
\end{tabular}

The result shows that $p>0.05$, thus the data is normally distributed.

Table 4: Paired Samples Statistics

\begin{tabular}{lccccc}
\hline & & \multicolumn{4}{c}{ Paired Samples Statistics } \\
\cline { 3 - 6 } & & Mean & N & Std. Deviation & Std. Error Mean \\
\hline \multirow{2}{*}{ Pair 1 } & Pre-test & 48.8333 & 24 & 5.45070 & 1.11262 \\
& Post-test & 86.0000 & 24 & 8.86615 & 1.80980 \\
\hline
\end{tabular}

Table 5: Paired-sample T-test

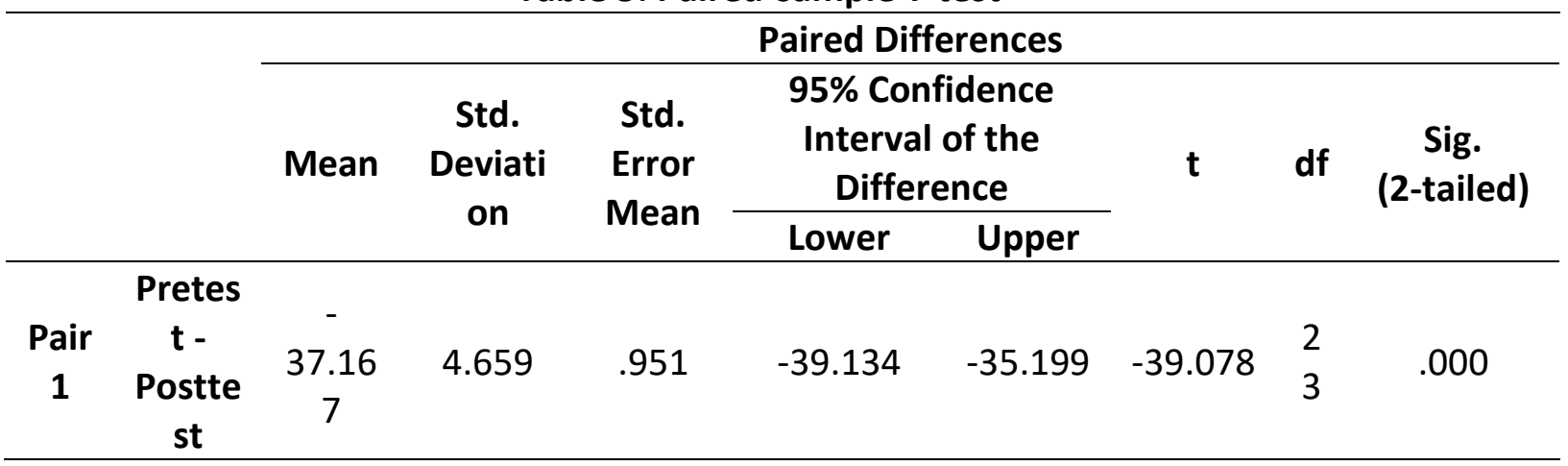

On average, based on the descriptive statistics shown in Table 4 and 5, it shows that the participants performed better after the implementation of VC4C card Game. Since the mean difference was negative (Table 5), the post-test results were better than the pre-test results. There is significant difference between pre-test and post-test, $t(23)=-39.078, p<.05, d=$ 7.98. The post-test had a higher performance $(M=86.00)$ compare to pre-test $(M=48.83)$. The results suggested that the significant value was smaller than alpha at .05 level of significance. The effect size is 7.98 which is greater than 0 and this shows that this VC4C Card Game has 
big positive effect on the pupils' vocabulary learning (Cohen, 1988). Thus, it can be concluded that VC4C Card Game had positive effects on the primary pupils' vocabulary learning.

Table 6 below describes the descriptive statistics of the data collected from the survey questionnaire. Based on the Model of Academic Success by York et al. (2015), Questions 1 to 3 focused on the "Attainment of Learning Outcome", Questions 4 to 6 emphasised on "Satisfaction in Learning", Questions 7 to 9 targeted on "Persistence in Learning", Questions 10 to 12 highlighted on "Acquired Learning Skills" and finally, Questions 13 to 15 dealt with "Performance / Academic Achievement".

Table 6: Data Collected from the Survey Questionnaire $(n=24)$

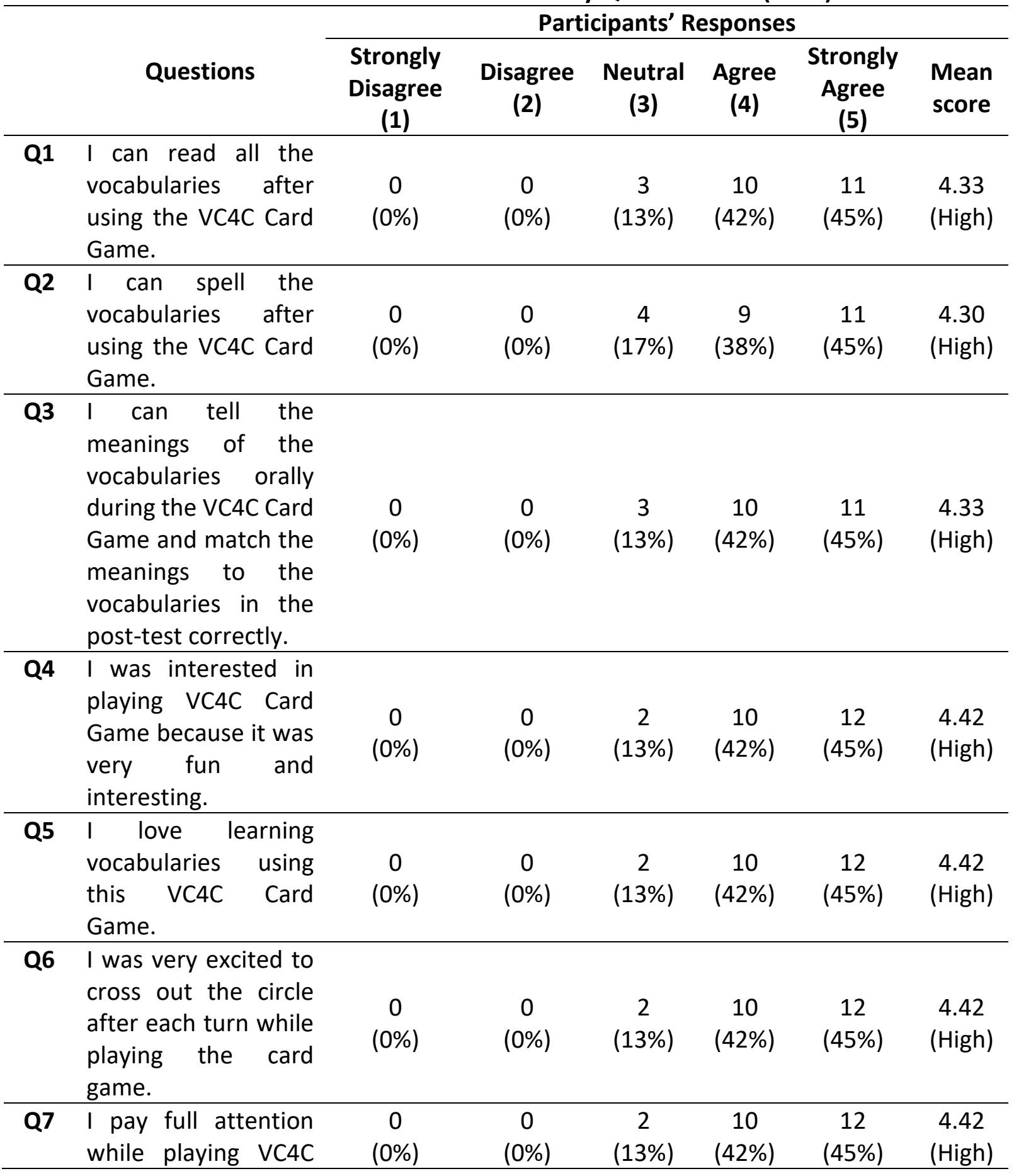




\begin{tabular}{|c|c|c|c|c|c|c|c|}
\hline & $\begin{array}{l}\text { Card Game with my } \\
\text { group members } \\
\text { without } \\
\text { guidance from mych } \\
\text { teacher. }\end{array}$ & & & & & & \\
\hline Q8 & $\begin{array}{l}\text { I am not afraid of } \\
\text { asking questions } \\
\text { whenever I face } \\
\text { difficulties } \\
\text { playing the card } \\
\text { game. }\end{array}$ & $\begin{array}{c}0 \\
(0 \%)\end{array}$ & $\begin{array}{c}0 \\
(0 \%)\end{array}$ & $\begin{array}{c}3 \\
(13 \%)\end{array}$ & $\begin{array}{c}10 \\
(42 \%)\end{array}$ & $\begin{array}{c}11 \\
(45 \%)\end{array}$ & $\begin{array}{c}4.33 \\
\text { (High) }\end{array}$ \\
\hline Q9 & $\begin{array}{l}\text { I like to compete with } \\
\text { my friends while } \\
\text { playing this card } \\
\text { game. }\end{array}$ & $\begin{array}{c}0 \\
(0 \%)\end{array}$ & $\begin{array}{c}0 \\
(0 \%)\end{array}$ & $\begin{array}{c}3 \\
(13 \%)\end{array}$ & $\begin{array}{c}10 \\
(42 \%)\end{array}$ & $\begin{array}{c}11 \\
(45 \%)\end{array}$ & $\begin{array}{c}4.33 \\
\text { (High) }\end{array}$ \\
\hline Q10 & $\begin{array}{l}\text { I was able to } \\
\text { remember and tell } \\
\text { the meanings of the } \\
\text { vocabularies after } \\
\text { learning using this } \\
\text { VC4C Card Game. }\end{array}$ & $\begin{array}{c}0 \\
(0 \%)\end{array}$ & $\begin{array}{c}0 \\
(0 \%)\end{array}$ & $\begin{array}{c}3 \\
(13 \%)\end{array}$ & $\begin{array}{c}10 \\
(42 \%)\end{array}$ & $\begin{array}{c}11 \\
(45 \%)\end{array}$ & $\begin{array}{c}4.33 \\
\text { (High) }\end{array}$ \\
\hline Q11 & $\begin{array}{l}\text { I was able to } \\
\text { remember and tell } \\
\text { the meanings of the } \\
\text { vocabularies while } \\
\text { answering the } \\
\text { questions in the post- } \\
\text { test given. }\end{array}$ & $\begin{array}{c}0 \\
(0 \%)\end{array}$ & $\begin{array}{c}0 \\
(0 \%)\end{array}$ & $\begin{array}{c}3 \\
(13 \%)\end{array}$ & $\begin{array}{c}10 \\
(42 \%)\end{array}$ & $\begin{array}{c}11 \\
(45 \%)\end{array}$ & $\begin{array}{c}4.33 \\
\text { (High) }\end{array}$ \\
\hline Q12 & $\begin{array}{l}\text { I was able to play } \\
\text { vC4C Card Game and } \\
\text { answer the questions } \\
\text { in the post-test given } \\
\text { with less guidance } \\
\text { from my friends or } \\
\text { teacher. }\end{array}$ & $\begin{array}{c}0 \\
(0 \%)\end{array}$ & $\begin{array}{c}0 \\
(0 \%)\end{array}$ & $\begin{array}{c}2 \\
(13 \%)\end{array}$ & $\begin{array}{c}10 \\
(42 \%)\end{array}$ & $\begin{array}{c}12 \\
(45 \%)\end{array}$ & $\begin{array}{c}4.42 \\
\text { (High) }\end{array}$ \\
\hline Q13 & $\begin{array}{l}\text { I was able to cross } \\
\text { out } 3 \text { circles and } \\
\text { above for each } \\
\text { session of this VC4C } \\
\text { Card Game. }\end{array}$ & $\begin{array}{c}0 \\
(0 \%)\end{array}$ & $\begin{array}{c}0 \\
(0 \%)\end{array}$ & $\begin{array}{c}3 \\
(13 \%)\end{array}$ & $\begin{array}{c}10 \\
(42 \%)\end{array}$ & $\begin{array}{c}11 \\
(45 \%)\end{array}$ & $\begin{array}{c}4.33 \\
\text { (High) }\end{array}$ \\
\hline Q14 & $\begin{array}{l}\text { I was able to score } \\
\text { more than } 3 \text { correct } \\
\text { in the VC4C Card } \\
\text { Game. }\end{array}$ & $\begin{array}{c}0 \\
(0 \%)\end{array}$ & $\begin{array}{c}0 \\
(0 \%)\end{array}$ & $\begin{array}{c}2 \\
(13 \%)\end{array}$ & $\begin{array}{c}10 \\
(42 \%)\end{array}$ & $\begin{array}{c}12 \\
(45 \%)\end{array}$ & $\begin{array}{c}4.42 \\
\text { (High) }\end{array}$ \\
\hline Q15 & $\begin{array}{l}\text { I was able to score } \\
\text { more than } 80 \% \text { in the } \\
\text { post-test given. }\end{array}$ & $\begin{array}{c}0 \\
(0 \%)\end{array}$ & $\begin{array}{c}0 \\
(0 \%)\end{array}$ & $\begin{array}{c}2 \\
(13 \%)\end{array}$ & $\begin{array}{c}10 \\
(42 \%)\end{array}$ & $\begin{array}{c}12 \\
(45 \%)\end{array}$ & $\begin{array}{c}4.42 \\
\text { (High) }\end{array}$ \\
\hline
\end{tabular}


As illustrated in Table 6, the element, "Satisfactory in Learning", gained the highest mean score of 4.42. This showed that the participants enjoyed and had fun acquiring vocabulary through the use of VC4C Card Game. High mean scores indicated a high level of agreement and satisfaction towards a highlighted criterion especially in a survey or questionnaire (Nunnally \& Bernstein, 1994; DeVellis, 2017). Hence, the aspect of "fun and meaningful learning" emphasised by the Ministry of Education (2018) was successfully achieved. For "Attainment of Learning Outcome", "Persistence in Learning" and "Acquired Learning Skills", most of the pupils responded positively with a high mean score of more than 4.00. Based on the feedback on these three elements, the VC4C Card Game had positively engaged the pupils in acquiring vocabularies. For the fifth element, "Performance or Academic Achievement", the pupils were able to "cross out 3 circles and above" and "score more than 3 correct" as they learn and play the VC4C Card Game. As for the post-test, $87 \%$ of the participants were able to obtain more than $80 \%$, which contributed to a high mean score of 4.42 . All in all, the overall mean scores of 4.37 (high level) for all 15 questions from the questionnaire indicated that the learners gained positive and constructive experiences in learning and acquiring the different vocabularies through VC4C Card Game.

Table 7 described the triangulated data collected from the observation checklist. From the two elements that were highlighted in the observation checklists, the remarks from the researchers were consistent with the remarks by the expert teacher.

Table 7: Data Collected from the Observation Checklist

\begin{tabular}{|c|c|c|c|}
\hline Elements & Checklist Items & & Written Remarks \\
\hline \multirow{6}{*}{$\begin{array}{l}\text { Improvement } \\
\text { in vocabulary } \\
\text { skills }\end{array}$} & \multirow{2}{*}{$\begin{array}{l}\text { Pupils are able to read } \\
\text { the vocabularies when } \\
\text { asked verbally by using } \\
\text { the VC4C Card Game. }\end{array}$} & Researcher & $\begin{array}{l}\text { Able to read the vocabularies } \\
\text { orally. }\end{array}$ \\
\hline & & $\begin{array}{l}\text { Expert } \\
\text { Teacher }\end{array}$ & $\begin{array}{l}\text { Can read the vocabularies } \\
\text { correctly. }\end{array}$ \\
\hline & \multirow{2}{*}{$\begin{array}{l}\text { Pupils are able to spell } \\
\text { the vocabularies when } \\
\text { asked verbally when } \\
\text { playing VC4C Card Game. }\end{array}$} & Researcher & $\begin{array}{l}\text { Able to spell the vocabularies } \\
\text { when playing the card game. }\end{array}$ \\
\hline & & $\begin{array}{l}\text { Expert } \\
\text { Teacher }\end{array}$ & $\begin{array}{l}\text { Can spell the vocabularies } \\
\text { correctly. }\end{array}$ \\
\hline & \multirow{2}{*}{$\begin{array}{l}\text { Pupils are able to tell the } \\
\text { meanings of the } \\
\text { vocabularies while } \\
\text { playing card game and } \\
\text { while answering post-test } \\
\text { correctly. }\end{array}$} & Researcher & $\begin{array}{c}\text { Able to tell the meanings of the } \\
\text { vocabularies while playing card } \\
\text { game and while answering post- } \\
\text { test correctly. }\end{array}$ \\
\hline & & $\begin{array}{l}\text { Expert } \\
\text { Teacher }\end{array}$ & $\begin{array}{l}\text { Can tell the meanings of each } \\
\text { vocabulary while playing card } \\
\text { game and while answering post- } \\
\text { test. }\end{array}$ \\
\hline & \multirow{2}{*}{$\begin{array}{l}\text { Pupils show interest in } \\
\text { playing this VC4C Card } \\
\text { Game by remembering } \\
\text { the spelling and the }\end{array}$} & Researcher & $\begin{array}{l}\text { Excitedly waiting for their turn } \\
\text { to play the card. }\end{array}$ \\
\hline & & $\begin{array}{l}\text { Expert } \\
\text { Teacher }\end{array}$ & $\begin{array}{l}\text { Interested in playing the card } \\
\text { and can remember the spelling } \\
\text { of the words. }\end{array}$ \\
\hline
\end{tabular}




\begin{tabular}{|c|c|c|c|}
\hline \multirow{5}{*}{$\begin{array}{l}\text { Motivational } \\
\text { level in } \\
\text { vocabulary } \\
\text { learning }\end{array}$} & $\begin{array}{l}\text { meanings of the } \\
\text { vocabularies. }\end{array}$ & & \\
\hline & \multirow{2}{*}{$\begin{array}{l}\text { Pupils have fun with their } \\
\text { friends while learning } \\
\text { vocabularies by using } \\
\text { VC4C Card Game. }\end{array}$} & Researcher & $\begin{array}{l}\text { Laughed loudly, help their } \\
\text { friends and exclaimed "Yes" } \\
\text { when answered correctly. }\end{array}$ \\
\hline & & $\begin{array}{l}\text { Expert } \\
\text { Teacher }\end{array}$ & $\begin{array}{c}\text { Smiled and laughed while } \\
\text { playing. }\end{array}$ \\
\hline & \multirow{2}{*}{$\begin{array}{l}\text { Pupils show excitement } \\
\text { when they managed to } \\
\text { cross one circle after } \\
\text { completing their turn for } \\
\text { each round of the card } \\
\text { game. }\end{array}$} & Researcher & $\begin{array}{l}\text { Giggled and showed eagerness } \\
\text { to cross one circle on the } \\
\text { Connect } 4 \text { Circle sheet. }\end{array}$ \\
\hline & & $\begin{array}{l}\text { Expert } \\
\text { Teacher }\end{array}$ & $\begin{array}{l}\text { Showing excited faces when } \\
\text { they managed to cross a circle. }\end{array}$ \\
\hline
\end{tabular}

As illustrated in Table 7, in the first element, "Improvement in vocabulary skills", the observed participants were able to "read", "spell" and "tell the meanings" of the different vocabularies. Based on the Model of Academic Success, York et al. (2015) asserted that learners capable of acquiring the three learning verbs, "read", "spell" and "tell the meanings", had achieved attainment in learning objective. In fact, the ability of learners to utilise mental and cognitive skills in performing descriptive explanations to explicate lesson learnt are evidences of success and accomplishment in learning (Indriyani \& Sugirin, 2019; Nishanthi, 2018). This indicated that VC4C Card Game assisted the learners to read each vocabulary, spell out the vocabularies and tell the meanings of each vocabulary learned successfully.

For the second element, "Motivational level in vocabulary learning", learners were observed to be highly interested in playing the card game. They enjoyed and had fun while playing the card game. Nevertheless, they were excited to cross out the circle on the Connect 4 Circles sheet after they successfully read, spell and tell the meanings of the vocabularies. Learners that exuded "fun", "excitement" and "interest" while learning would experience satisfaction in acquiring critical input and had longer or permanent retention on the knowledge learned (York et al., 2015). In the form of a game, the VC4C Card Game allowed the learners to learn and remember the vocabularies in a fun and meaningful way, so as to encourage acquisition and familiarity in all the 20 vocabularies. Walker and Rinaldi (2019) also acknowledged the importance of fun learning in lowering learning anxiety and improving learning motivation as part young learners experience towards academic success. Thus, the application of the VC4C Card Game had impacted positively in engaging excitement and acquisition in learning vocabularies.

\section{Discussion}

Enhancing the Vocabulary Skills among Learners

From the pre and post-test results, it can be concluded that the use of the VC4C Card Game managed to enhance the vocabulary skill among the Year One participants. In the pre-test, majority of the research participants scored less than $60 \%$. After the implementation of the VC4C Card Game, the post-test showed a significant increase in the score of the research participants where all 24 participants had scored more than $70 \%$ in their post-tests. This shows that the implementation of the VC4C Card Game managed to reinforce the vocabularies learned among the pupils, which also adhered to the aim of this paper. Undeniably, playing games which are educational to pupils would give a chance for them to 
experience a more positive and encouraging learning environment (Takeuchi \& Vaala, 2014). Through the post-test, it was also found that using the VC4C Card Game could enhance the pupils' ability in memorising new vocabularies and encourage the pupils' interaction in remembering the spelling and the meaning of the vocabularies. Vygotsky (1978) mentioned that games help in developing problem solving skills and enhancing the creativity and communication among primary pupils. The pupils have to put in effort to remember not only the spelling of the vocabularies but the meanings too. Past researchers also believe that the use of games can help teachers to create various contexts in which pupils can use the language for communication, exchanging information and expressing their own opinions especially in the spelling of new vocabularies (Derakhshan \& Khatir, 2015).

Besides, the survey questionnaire showed high mean scores obtained from the research participants. It shows that most of the pupils agreed that they know how to spell and remember the meanings of the words that they had learned. This shows the effectiveness of using games in developing the pupils' vocabulary skill. Taghiadeh et al. (2017) also supports that the use of games enables children to learn vocabulary better than using traditional ways.

Moreover, the observation checklist also showed that the participants were able to remember the vocabularies through the application of VC4C Card Game. They were able to show improvements in their vocabulary learning and they were also encouraged to learn more vocabularies by using the VC4C Card Game. York et al. (2015) believes that the ideal behavioural interactions shown by the participants signify their efforts to achieve and obtain acquisition of the vocabularies and insight in learning. In fact, VC4C Card Game supported and aided participants' acquisition and improved their ability to read, spell and tell the meanings of the vocabularies. Therefore, it can be concluded that the use of VC4C Card Game is effective in enhancing the learners' vocabulary skills.

\section{Encouraging the Learners to Learn Vocabularies}

From the survey questionnaire, it showed that the VC4C Card Game had achieved its potential in encouraging learners to learn vocabularies. The research participants showed positive responses and had high mean score as majority of them agreed to the statements in the survey questionnaire. The research participants agreed that they were interested and had fun playing the VC4C Card Game. This indicates that learners were motivated to learn new vocabularies after the implementation of the VC4C Card Game. According to AI Neyadi (2007), motivation is one of the important factors in learning a language and a supportive environment that stimulates and engages the pupils in learning will ensure active participation in the learning of new vocabularies.

Apart from that, from the observation checklist, it was also found that most of the participants collaborated with their peers by helping them in giving the meaning of the vocabularies formed. Games are effective in learning vocabulary because they usually involve friendly competition and create cooperative learning environment to the pupils (Derakhshan \& Khatir, 2015). The communication between the learners showed that they were interested and participated actively in the learner-centred activity which provided a meaningful experience to the pupils as they interacted with each other. As a result, the acquisition of language vocabulary is encouraged (Segal-Drori et al., 2010). Therefore, it can be concluded that VC4C Card Game managed to encourage pupils to interact with each other and to participate actively in the learning of new vocabularies. Nevertheless, using games makes pupils participate actively in this 21st century technological society and improves their reading as well as spelling of the vocabularies (Shahriarpour \& Kafi, 2014; Shabaneh \& Farrah, 
2019). In short, the learners were able to enjoy while learning and showed great improvements in vocabulary learning.

\section{Conclusion and Implications}

The use of VC4C Card Game can help to enhance the pupils' vocabulary skills. In this research, it was proven to be effective as the data collected from the pre-test, post-test, survey questionnaire and observation checklist showed that majority of the participants had positive experiences in learning vocabulary through the VC4C Card Game, aside from having better memory retention of the vocabularies learned; in which promoted the learners' interest in expanding their vocabulary bank. The pupils' level of motivation was observed to be improving and they provided positive feedbacks to the use of VC4C Card Game in learning new vocabularies. For pupils, the use of VC4C Card Game is a fun and interactive way in learning new vocabularies without fully depending on memorising and drilling. In fact, the $4 C^{\prime} s$ and $1 \mathrm{~V}$ could also be enhanced among pupils, in line with the current 21st century learning system.

As for teachers, it provides a platform for a pupil-centred learning environment where pupils can carry out hands-on activities. This reduced the teacher's involvement in the learning process and allowed more autonomy for the pupils in learning the new and unfamiliar vocabularies. As independent word learners, pupils will learn best by making sense of their own vocabulary and internalising it. Through the usage of the VC4C Card Game, the teacher is only required to monitor the pupils' learning. Thus, VC4C Card Game shows the relevance to the improvement in the methodology of teaching vocabulary in a fun, interesting and meaningful way. As suggestions for future researches, it would be interesting to see this VC4C Card Game being used to teach other language skills such as writing and speaking. In fact, it would be good to be used to teach other subjects as well.

All in all, vocabulary acquisition among the young learners is often found to be tedious and challenging. Therefore, using appropriate methods and techniques for the teaching and learning of vocabulary is deemed crucial in order to help ease the knowledge acquisition among learners. In this context, the application of card game-based teaching and learning strategies has encouraged researchers worldwide to examine the strategies that would fit their respective situations or learners best. In accordance with this, the integration of card game-based strategies in vocabulary learning will definitely have huge impacts on vocabulary learning and acquisition among young learners. In other words, this research clearly shows the efficacy of card game-based learning methods among language learners. The results from the research showed that learners are able to benefit a lot from this card game-based learning method as they show high potential to improve the young learners' vocabulary competence and simultaneously, increase their level of English language proficiency as well.

\section{References}

Akdogan, E. (2017). Developing vocabulary in game activities and game materials. Journal of Teaching and Education, 7(1), 31-66.

Al Neyadi, O. (2007). The effects of using games to reinforce vocabulary learning. In Marifa H.C.T. (Ed.), Action research and initial teacher education in the UAE (pp.99-1-7). HCT Press, UAE.

Alqahtani, M. (2017). The importance of vocabulary in language learning and how to be taught. International of Teaching and Education, 3(3), 21-34.

Asún, R. A., Rdz-Navarro, K., \& Alvarado, J. M. (2016). Developing multidimensional Likert 
scales using item factor analysis: The case of four-point items. Sociological Methods \& Research, 45(1), 109-133. doi:10.1177/0049124114566716

Bakhsh, S. A. (2016). Using games as a tool in teaching vocabulary to young learners. English Language Teaching, 9(7), 120-128. doi:10.5539/elt.v9n7p120

Bavi, F. (2018). The effect of using fun activities on learning vocabulary at the elementary level. Journal of Language Teaching and Research, 9(3), 629-639.

Calvo-Ferrer, J. R. (2017). Educational games as stand-alone learning tools and their motivational effects on L2 vocabulary acquisition and perceived learning gains. British Journal of Educational Technology, 48(2), 264-278. https://doi.org/10.1111/bjet.12387

Charman, S. (2017). The research: Aims and methods. Police Socialisation, Identity and Culture: Becoming Blue. pp.171-187. Cham: Springer International Publishing. doi:10.1007/978-3-319-63070-0_7.

Chu, H., \& Ke, Q. (2017). Research methods: What's in the name? Library \& Information Science Research, 39(4), 284-294. doi:https://doi.org/10.1016/j.lisr.2017.11.001.

Cohen, J. (1988). Statistical Power Analysis for the Behavioural Sciences (2nd ed.). NJ: Lawrence Erlbaum: Hillsdale.

Conwell, E. (2017). Are homophones acoustically distinguished in child-directed speech? Language Learning and Development, 13(3), 262-273.

Collatto, D. C., Dresch, A., Lacerda, D. P., \& Bentz, I. G. (2018). Is action design research indeed necessary? Analysis and synergies between action research and design science research. Systemic Practice and Action Research, 31(3), 239-267. doi:10.1007/s11213- 017-9424-9.

Chai, K. N., Jong, B., Thomas, S., Dison, M. A., Yunus, M. M., \& Suliman, A. (2020). Enhancing Malaysian Primary Pupils' Vocabulary Skills using Pocable Game and Pear Deck. International Journal of Learning, Teaching and Educational Research, 19(6), 145-160. doi:https://doi.org/10.26803/ijlter.19.6.9

Chuah, K. H. (2014). Promoting collaborative action research among in-service teacher through lesson study: A proposed approach. Jurnal Penyelidikan Tindakan IPBL Tahun 2014, 8, 49-57.

Creswell, J. W., \& Guetterman, T. C. (2019). Educational research: Planning, conducting, and evaluating quantitative and qualitative research. New York, NY: Pearson.

Denscombe, M. (2014). The good research guide: For small-scale social research projects. Maidenhead, England: McGraw-Hill/Open University Press.

Derakhshan, A., \& Khatir, E. D. (2015). The effects of using games on English vocabulary learning. Journal of Applied Linguistics and Language Research, 2(3), 39-47.

DeVellis, R. F. (2017). Scale Development : Theory and Applications.

Dick, B. (2015). Reflections on the SAGE encyclopedia of action research and what it says about action research and its methodologies. Action Research, 13(4), 431444. doi:10.1177/1476750315573593.

Etikan, I., Musa S. A., Alkassim, R. S. (2016). Comparison of convenience sampling and purposive sampling. American Journal of Theoretical and Applied Statistics, 5(1), pp. 1-4. doi: 10.11648/j.ajtas.20160501.11.

Jan, M., \& Gaydos, M. (2016). What is game-based learning? Past, present and future. Educational Technological Publications, 56(3), 6-11. 
Ginsburgh, V., Melitz, J., \& Weber, S. (2016). The Palgrave handbook of economics and language. London: Palgrave Macmillan https://doi.org/10.1007/978-1-137-325051_21.

Hambleton, R. K., \& Li, S. (2014). Criterion-referenced assessment. Wiley StatsRef: Statistics Reference Online 1-8.

Hariffin, A., \& Said, N. E. M. (2019). The effects of captioned videos on primary ESL learners' vocabulary acquisition in a Malaysian rural setting. International Journal of Humanities, Philosophy, and Language, 2(7), 23-37.

Hidayat, N. (2016). Improving students' vocabulary achievement through word game. Journal of Educators Society, 1(2), 95-104.

Indriyani, A., \& Sugirin. (2019). The impact of vocabulary learning strategies. 3rd International Conference on Current Issues in Education (ICCIE 2018) (pp. 113-117). Paris: Atlantis Press.

Kunnu, W., Uiphanit, T., \& Sukwises, A. (2016). The development of vocabulary memorization by using games. International Journal of Social Science and Humanity, 6(6), 419-422. Retrieved from http://www.ijssh.org/vol6/683-H019.pdf

Laidlaw, M. (1992). Action research: A guide for use on initial teacher education programmes. Action Research.Net. http://www.actionresearch.net/moira.shtml [10 September 2020].

Lewin, K. (1946). Action research and minority problems. Journal of Social Issues, 4(2), 3446. http://www.comp.dit.ie/dgordon/Courses/ILT/ILT0003/ActionResearch MinortyProblems.pdfAction.

Lie, W., \& Yunus, M. M. (2018). Pen pals are now in your fingertips - A global collaboration online project to develop writing skills. Creative Education, 9(15), 2491-2504. doi: 10.4236/ce.2018.915188

Lim, K. I., Yunus, M. M., \& Amin, M. E. (2017). Build me up: Overcoming writing problems among pupils in a rural primary school in Belaga, Sarawak, Malaysia. Jurnal Pendidikan Humaniora, 5(1), 1-7.

Liu, S., \& Liu, J. (2015). The application of games in English vocabulary teaching in kindergartens. Sino-US English Teaching, 12(8), 561-567.

Lok, B., McNaught, C., \& Young, K. (2016). Criterion-referenced and norm-referenced assessments: Compatibility and complementarity. Assessment \& Evaluation in Higher Education, 41(3), 450-465. doi:10.1080/02602938.2015.1022136

Mashhadia, F., \& Jamalifar, G. (2015). Second language vocabulary learning through visual and textual representation. ProcediaSocial and Behavioral Sciences, 192, 298-307. https://doi.org/10.1016/j.sbspro.2015.06.043.

McKay, S. L. (2018). English as an international language: What is it and what it means for pedagogy. RELC Journal, 49(1), 9-23.

Ministry of Education. (2018). English language education reform in Malaysia: The roadmap 2015-2025. Retrieved September 10, 2020, from https://anyflip.com/detl/zspi/basic

Ministry of Education. (2017). Standard Curriculum Document (DSKP) Year 1. Ministry of Education.

Misbah, N., Mohamad, M., Yunus, M. M., \& Ya'acob, A. (2017). Identifying the factors contributing to students' difficulties in the English language learning. Creative Education, 8, 1999-2008. doi: 10.4236/ce.2017.813136.

Nunnally, J. C. \& Bernstein, I. . (1994). The Assessment of Reliability. Psychometric Theory, 3, 248-292. 
Nie, Y., \& Li, Z. (2017). A study of vocabulary learning strategies used by excellent English learners. Asian Academic Press, 4, 101-106.

Nishanthi, R. (2018). Importance of learning English in today's world. International Journal of Trend in Scientific Research and Development (IJTSRD), 3(1), 871-874.

Perveen, A., Asif, M., \& Mehmood, S. (2016). Effectiveness of language games in second language vocabulary acquisition. Sci. Int. (Lahore), 28(1), 633-637. ISSN:1013-5316.

Pirrie, L. A. (2017). Teaching and learning vocabulary through games and translation in the EFL classroom: A case study. Universitat.

Pomerantz, A., \& Bell, N. D. (2007). Learning to play, playing to learn: FL learners as multicompetent language users. Applied Linguistics, 28(4), 556-578.

Rachmawati, D. (2018). Vocabulary learning strategies used by first year of EFL students. English Journal of Merdeka, 2(2), 1-6.

Reddy, M. S. (2016). Importance of English language in today's world. International Journal of Academic Research, 3(4), 179-184.

Saeed, M., \& Ghayour, M. (2017). The effect of educational computerised games on learning English spelling among Iranian children. The Reading Matrix: An International Online Journal, 17(2), 165-178.

Segal-Drori, O., Korat, O., Shamir, A., \& Klein, P. S. (2010). Reading electronic and printed books with and without adult instruction: Effects on emergent reading. Reading and Writing, 23(8), 913-930.

Shabaneh, Y., \& Farrah, M. (2019). The effect of games on vocabulary retention. Indonesian Journal of Learning and Instruction, 2(1), 79-90.

Shahriarpour, N. \& Kafi, Z. (2014). The effect of playing digital games on Iranian intermediate ELF learners' motivation toward learning English vocabularies. Procedia-Social and Behavioural Sciences, 98, 1738-1743.

Sousa, M., \& Rocha, A. (2019). Leadership styles and skills developed through game-based learning. Journal of Business Research, 94, 360-366.

Taber, K. S. (2018). The use of Cronbach's Alpha when developing and reporting research instruments in science education. Research in Science Education, 48(6), 1273-1296. doi:10.1007/s11165-016-9602-2

Taghiadeh, M., Vaezi, S., \& Ravan, M. (2017). Digital games, songs and flashcards and their effects on vocabulary knowledge of Iranian preschoolers. Studies, 5(4), 156-171.

Takeuchi, L. M., \& Vaala, S. (2014). Level up learning: A national survey on teaching with digital games. New York: The Joan Ganz Cooney Center at Sesame Workshop.

Taylor, N., Greenberg, D., \& Terry, N. (2016). The relationship between parents' literacy skills and their preschool children's emergent literacy skills. Journal of Research and Practice for Adult Literacy, Secondary, and Basic Education, 5(2), 5.

Thirusanku, J., \& Yunus, M. M. (2012). Status of English in Malaysia. Asian Social Science, 10(14), 254-260. ISSN 1911-2017.

Viera, R. T. (2016). Vocabulary knowledge in the production of written texts: A case study on EFL language learners. Revista Tecnologica ESPOL, 30(3), 89-105.

Vygotsky, L. (1978). Interaction between learning and development. California: W.H. Freeman Company.

Walker, M. A., \& Rinaldi, C. (2019). Children's social and emotional functioning and academic success in preschool: The role of internalizing problems and adaptive skills. Contemporary School Psychology. doi:10.1007/s40688-019-00232-5 
White, K., \& McCoy, L. (2019). Effects of game-based learning on attitude and achievement in elementary mathematics. Networks: An Online Journal for Teacher Research, 21(1), 117.

York, T., Gibson III, C., \& Rankin, S. (2015). Defining and measuring academic success. Practice Assessment, Research \& Evaluation, 20(5), 1-20. https://pareonline.net/ getvn. asp?v=20\&n=5 [10 September 2020]

Yunus, M. M., \& Ek Hern, G. (2011). Malaysian undergraduates' perceptions and attitudes on bilingual education. Procedia Social and Behavioural Sciences, 15, 2618-2622.

Yunus, M. M., Lau, E. Y.Y., Khair, A. H. M., Yusof, N. M. (2020). Acquisition of vocabulary in primary schools via GoPic with QR code. International Journal of English Language and Literature Studies, 9(3), 121-131. doi: 10.18488/journal.23.2020.93.121.131.

Yunus, M. M., Kiing, J. L., \& Salehi, H. (2013). Using blogs to promote writing skill in ESL classroom. Proceedings of the 4th International Conference on Education and Educational Technologies (EET '13).

Yunus, M. M., Salehi, H., \& Amini, M. (2016). Impact of using CALL on Iranian's EFL learners' vocabulary knowledge. English Language Teaching, 9(1), 173-187. ISSN: 1916-4742. 


\section{Appendix 1: Pre-test and Post-test}

NAME:

SCORE: $\quad / 20$

Write the words and match the meanings correctly.

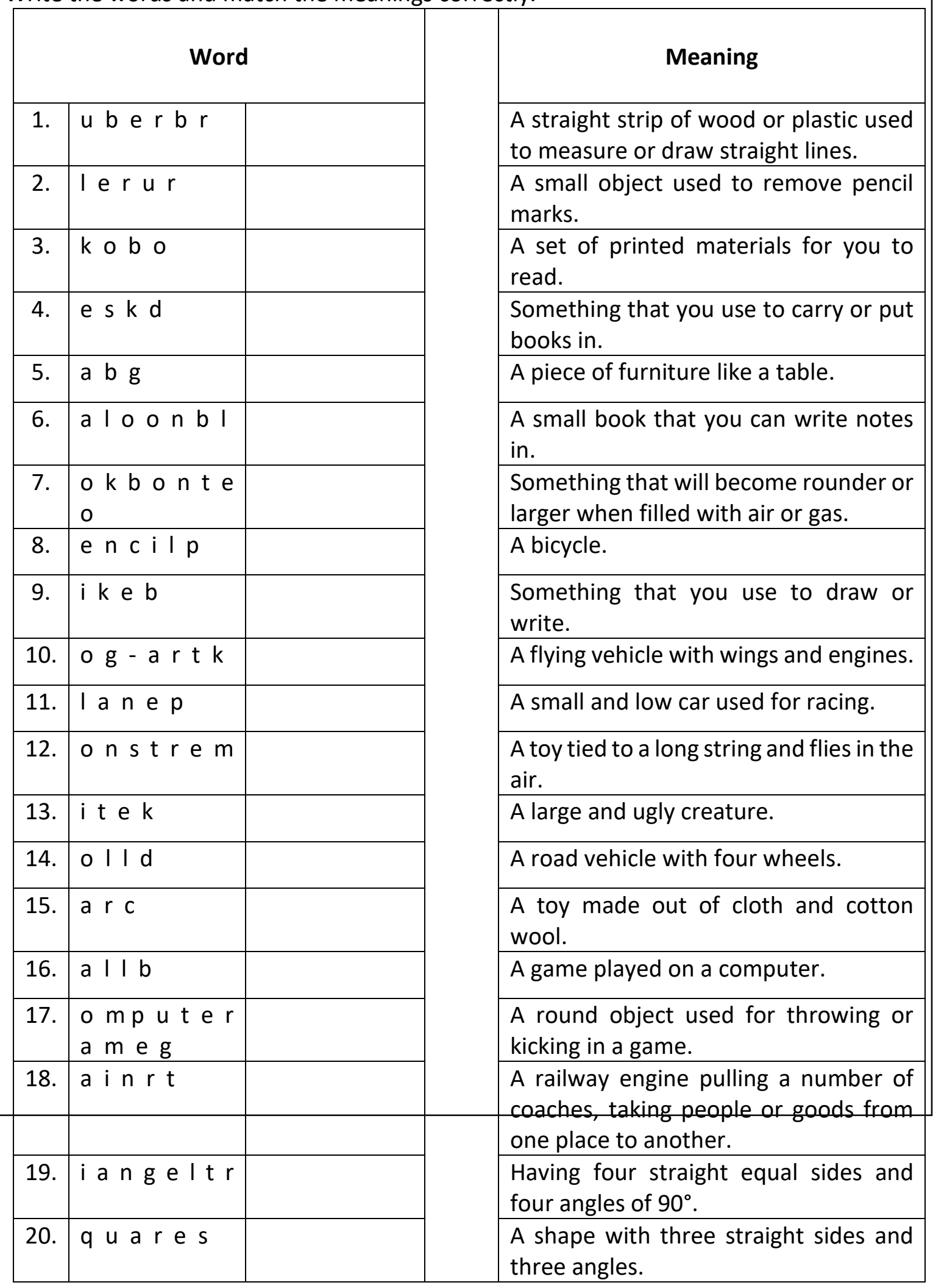




\section{Appendix 2: Survey Questionnaire}

Below are $\mathbf{1 5}$ statements about your experience in using VC4C Card Game. There is no right or wrong answers. Each statement has 5 options. Tick (/) only 1 option that suits you most for each statement.

\begin{tabular}{|c|c|c|c|c|c|c|}
\hline \multirow{2}{*}{$\begin{array}{l}\text { No } \\
\text {. }\end{array}$} & \multirow{2}{*}{ Statements } & \multicolumn{5}{|c|}{ Scales } \\
\hline & & $\begin{array}{l}\text { Strongl } \\
y \\
\text { Disagre } \\
\text { e }\end{array}$ & $\begin{array}{l}\text { Disagre } \\
\stackrel{e}{\frown}\end{array}$ & $\begin{array}{c}\text { Neutr } \\
\text { al } \\
-0\end{array}$ & Agree & $\begin{array}{l}\text { Strongl } \\
\text { y Agree }\end{array}$ \\
\hline 1. & $\begin{array}{l}\text { I can read all the vocabularies } \\
\text { after using the VC4C Card } \\
\text { Game. }\end{array}$ & 1 & 2 & 3 & 4 & 5 \\
\hline 2. & $\begin{array}{l}\text { I can spell the vocabularies } \\
\text { after using the VC4C Card } \\
\text { Game. }\end{array}$ & 1 & 2 & 3 & 4 & 5 \\
\hline 3. & $\begin{array}{l}\text { I can tell the meanings of the } \\
\text { vocabularies orally during the } \\
\text { VC4C Card Game and match } \\
\text { the meanings to the } \\
\text { vocabularies in the post-test } \\
\text { correctly. }\end{array}$ & 1 & 2 & 3 & 4 & 5 \\
\hline 4. & $\begin{array}{l}\text { I was interested in playing } \\
\text { VC4C Card Game because it } \\
\text { was very fun and interesting. }\end{array}$ & 1 & 2 & 3 & 4 & 5 \\
\hline 5. & $\begin{array}{l}\text { I love learning vocabularies } \\
\text { using this VC4C Card Game. }\end{array}$ & 1 & 2 & 3 & 4 & 5 \\
\hline 6. & $\begin{array}{l}\text { I was very excited to cross out } \\
\text { the circle after each turn } \\
\text { while playing the card game. }\end{array}$ & 1 & 2 & 3 & 4 & 5 \\
\hline 7. & $\begin{array}{l}\text { I pay full attention while } \\
\text { playing VC4C Card Game with } \\
\text { my group members without } \\
\text { much guidance from my } \\
\text { teacher. }\end{array}$ & 1 & 2 & 3 & 4 & 5 \\
\hline 8. & $\begin{array}{l}\text { I am not afraid of asking } \\
\text { questions whenever I face } \\
\text { difficulties while playing the } \\
\text { card game. }\end{array}$ & 1 & 2 & 3 & 4 & 5 \\
\hline
\end{tabular}




\begin{tabular}{|c|c|c|c|c|c|c|}
\hline 9. & $\begin{array}{l}\text { I like to compete with my } \\
\text { friends while playing this card } \\
\text { game. }\end{array}$ & 1 & 2 & 3 & 4 & 5 \\
\hline 10. & $\begin{array}{l}\text { I was able to remember and } \\
\text { tell the meanings of the } \\
\text { vocabularies after learning } \\
\text { using this VC4C Card Game. }\end{array}$ & 1 & 2 & 3 & 4 & 5 \\
\hline 11. & $\begin{array}{l}\text { I was able to remember and } \\
\text { tell the meanings of the } \\
\text { vocabularies while answering } \\
\text { the questions in the post-test } \\
\text { given. }\end{array}$ & 1 & 2 & 3 & 4 & 5 \\
\hline 12. & $\begin{array}{l}\text { I was able to play VC4C Card } \\
\text { Game and answer the } \\
\text { questions in the post-test } \\
\text { given with less guidance from } \\
\text { my friends or teacher. }\end{array}$ & 1 & 2 & 3 & 4 & 5 \\
\hline 13. & $\begin{array}{l}\text { I was able to cross out } 3 \\
\text { circles and above for each } \\
\text { session of this VC4C Card } \\
\text { Game. }\end{array}$ & 1 & 2 & 3 & 4 & 5 \\
\hline 14. & $\begin{array}{l}\text { I was able to score more than } \\
3 \text { correct in the VC4C Card } \\
\text { Game. }\end{array}$ & 1 & 2 & 3 & 4 & 5 \\
\hline 15. & $\begin{array}{l}\text { I was able to score more than } \\
80 \% \text { in the post-test given. }\end{array}$ & 1 & 2 & 3 & 4 & 5 \\
\hline
\end{tabular}




\section{Appendix 3: Observation Checklist}

\begin{tabular}{|c|c|c|c|}
\hline Elements & Checklist Items & & Written Remarks \\
\hline \multirow{6}{*}{$\begin{array}{l}\text { Improvements } \\
\text { in vocabulary } \\
\text { skills }\end{array}$} & \multirow{2}{*}{$\begin{array}{l}\text { Pupils are able to read the } \\
\text { vocabularies when asked } \\
\text { verbally by using the VC4C } \\
\text { Card Game. }\end{array}$} & Researcher & \\
\hline & & Expert Teacher & \\
\hline & \multirow{2}{*}{$\begin{array}{c}\text { Pupils are able to spell the } \\
\text { vocabularies when asked } \\
\text { verbally when playing VC4C } \\
\text { Card Game. }\end{array}$} & Researcher & \\
\hline & & Expert Teacher & \\
\hline & \multirow{2}{*}{$\begin{array}{c}\text { Pupils are able to tell the } \\
\text { meanings of the vocabularies } \\
\text { while playing card game and } \\
\text { while answering post-test } \\
\text { correctly. }\end{array}$} & Researcher & \\
\hline & & Expert Teacher & \\
\hline \multirow{6}{*}{$\begin{array}{l}\text { Motivational } \\
\text { level in } \\
\text { vocabulary } \\
\text { learning }\end{array}$} & \multirow{2}{*}{$\begin{array}{l}\text { Pupils show interest in } \\
\text { playing this VC4C Card Game } \\
\text { by remembering the spelling } \\
\text { and the meanings of the } \\
\text { vocabularies. }\end{array}$} & Researcher & \\
\hline & & Expert Teacher & \\
\hline & \multirow{2}{*}{$\begin{array}{l}\text { Pupils have fun with their } \\
\text { friends while learning } \\
\text { vocabularies by using VC4C } \\
\text { Card Game. }\end{array}$} & Researcher & \\
\hline & & Expert Teacher & \\
\hline & \multirow{2}{*}{$\begin{array}{l}\text { Pupils show excitement when } \\
\text { they managed to cross one } \\
\text { circle after completing their } \\
\text { turn for each round of the } \\
\text { card game. }\end{array}$} & Researcher & \\
\hline & & Expert Teacher & \\
\hline
\end{tabular}

